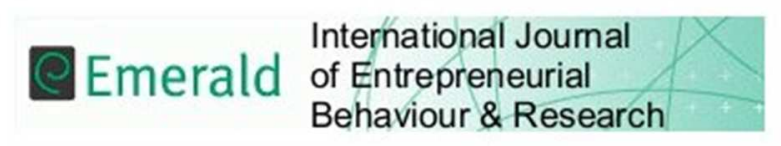

\title{
IS WOMEN EMPOWERMENT A ZERO SUM GAME? UNINTENDED CONSEQUENCES OF MICROFINANCE FOR WOMEN'S EMPOWERMENT IN GHANA
}

\begin{tabular}{|r|l|}
\hline Journal: & International Journal of Entrepreneurial Behavior \& Research \\
\hline Manuscript ID & IJEBR-04-2017-0114.R3 \\
\hline Manuscript Type: & Research Paper \\
\hline Keywords: & Microfinance, Women Empowerment, Unintended Consequences, Ghana \\
\hline \multicolumn{2}{|c}{} \\
\hline
\end{tabular}

\section{SCHOLARONE ${ }^{\text {TW }}$ \\ Manuscripts}




\section{IS WOMEN EMPOWERMENT A ZERO SUM GAME? UNINTENDED CONSEQUENCES OF MICROFINANCE FOR WOMEN'S EMPOWERMENT IN GHANA}




\section{ABSTRACT}

Purpose: Against the background of growing concerns that development interventions can sometimes be a zero-sum game, this paper examines the unintended consequences of microfinance for women empowerment in Ghana.

Design/methodology/approach: The study employs a participatory mixed-method approach including household questionnaire surveys, focus group discussions and key informant interviews to investigate the dynamics of microfinance effects on women in communities of different vulnerability status in Ghana.

Findings: The results of hierarchical regression, triadic closure and thematic analyses demonstrate that the economic benefits of microfinance for women is also directly associated with conflicts amongst spouses, girl child labour, polygyny and the neglect of perceived female-domestic responsibilities due to women's devotion to their enterprises.

Originality/value: In the light of limited empirical evidence on potentially negative impacts of women empowerment interventions in Africa, this paper fills a critical gap in knowledge that will enable NGOs, policy makers and other stakeholders to design and implement more effective interventions that mitigate undesirable consequences.

Keywords - Microfinance; Women Empowerment; Unintended Consequences; Ghana. 


\section{INTRODUCTION}

Development interventions can sometime have unintended, and rather significant, consequences. More often than not, interventions aimed at resolving or mitigating one problem can end up precipitating new problems or aggravating existing ones. For instance, uptake of technological innovations is usually a key part of firm strategy in order for the firm to improve their productivity and achieve competitive advantage. Conversely, technological innovations are known to lead to increased unemployment and greater inequality as firms rely more and more on automation and less on human workers (Frey and Osborne, 2015; Sveiby et al., 2009). Similarly, interventions aimed at improving the lives of slum dwellers are sometimes used to justify state-sponsored evictions of slum dwellers and their settlements (Meth, 2013). This has led some practitioners to express the concern that, if not well designed and carefully implemented, development interventions can be a zero sum game where what is gained in one area is lost, in equal or greater measure, in other areas.

One of the areas of growing concerns, especially in sub-Saharan African contexts, is women economic empowerment schemes. Within the past decade, there is increasing awareness that interventions aimed at improving poor women's financial conditions can have negative, undesirable consequences on women's wellbeing. For example, while women economic empowerment can contribute to household welfare due to increased financial power of women, it can also alter power relations within the household and thus lead to increased risk of domestic violence from men trying to re-assert control (Aísa, 2014). The risk of domestic violence is especially high in sociocultural contexts where gender roles are rigidly defined and women economic empowerment disrupts existing gender norms by facilitating new models of behaviour (Hughes et al., 2015). Given the prevalence of gendered poverty in subSaharan Africa (Blackden et al., 2006) and the growing interest in women empowerment schemes to mitigate gendered poverty, there is a critical need for practitioners to engage carefully with the challenge of unintended consequences in their design of women empowerment interventions. Sadly, there is little empirical data illuminating these unintended consequences. This paper fills this critical gap in knowledge.

A number of scholars have argued that microfinance for women can be effective in 
alleviating poverty and improving enterprise development (Ogato, 2013; Salia, 2014; Srivinisa and Shivanna, 2014). Within this context, Al-Dajani and Marlow (2013) observed that marginalised subordinated women are empowered through their home-based enterprises. Case studies in Asia indicate that access to micro-finance enhances women's economic independence and bargaining powers, but the positive impacts are often limited and hindered by a culture of patriarchy pervasive in Asia (Kulkarni, 2011). Similarly, in African countries such as Ghana, women's inability to contribute to household income is due to their weaker financial and social position within society (Agyei et al., 2016). Therefore, it is argued that access to microfinance, in addition to offering employment, may also improve female psychological and social empowerment (Ganle et al., 2015; Seidu and Bambangi, 2006). However, little scholarly attention has been given to the corresponding impact of microfinance on family cohesions and women well-being. For example, women business owners often experience gender discrimination and sexual harassment (Zeidan and Bahrami, 2011), and these experiences discourage women from taking on entrepreneurial activities. This study examines the microfinance literature, in order to understand the unintended consequences emanating from microfinance in Ghana; their impact on women's empowerment, family structures and challenges for microfinance institutions and the wider community.

The rest of the paper is organised as follows. Section one considers the theoretical perspectives on microfinance for women empowerment. Section two describes sources, the data set and variables used. Section three analyses the empirical findings and Section four pulls together the evidence presented and highlights the alternative explanation to an established and well embedded narrative.

\section{GENDER AND FINANCE}

The theory of gender empowerment is situated in a construct of social interaction (Stromquist, 2015). In recent years, scholars have engaged in debates about how men and women "do gender" and how they contribute to the construction of gender identities by engaging in a process of reciprocal positioning that impacts upon poverty (Darlington and Mulvaney, 2014). Klugman et al. (2014) observed that the process of shared growth 
eliminates extreme poverty. This perspective points to the nexus between gender empowerment and poverty which has implications for conceptualizing women's empowerment. The nature and form of poverty is situated in levels of inequalities (GarcíaRodríguez, 2012). Thus, powerlessness, lack of representation and lack of freedom is a suitable starting point for describing poverty (Lang, 2011).

Micro finance institutions (MFIs) can be effective in improving women's gender reciprocal positioning by helping them to overcome the finance gap. Blattman et al. (2013) observed that access to finance through MFIs has the potential to accelerate the growth of womenowned enterprises. However, negative outcomes affecting family and social cohesion have the potential to negate female achievements, for example through the experience of domestic violence. Thus, this paper seeks to test the hypothesis:

$\mathrm{H}_{1}$ : There is a significantly positive relationship between the success of MFI's services for women`s empowerment and poor family cohesion.

Family cohesion entails paternal and maternal warmth (Jaggers et al., 2015) and it is considered an essential attribute for healthy family functioning (Jin, 2015). Friggeri et al. (2011) suggests that cohesion theory builds upon a notion of triadic closure. A property which states that given three nodes $\Upsilon, X$ and $\Phi$; if there is a strong tie between $\Upsilon-\mathrm{X}$ and $\Upsilon$ $\Phi$ it is likely there will be a strong or weak tie between $X-\Phi$ (Opsahl, 2013). To simplify these relationships and to put it in the context of this study, it is proposed that, for example, $\Upsilon$ $=$ negative trust; $X=$ microfinance related conflict and $\Phi=$ poor family cohesion. Based on this the study can predict that if Negative Trust (NT) shares a tie with both Microfinance Related Conflict (MRC) and Poor Family Cohesion (COH), then, a link between microfinance related conflict and poor family cohesion can be anticipated, be it weak or strong.

\section{[Figure 1.0 about here]}

Consistent with the conceptualisation of the unintended consequences of microfinance on female empowerment from the literature reviewed, this study is guided by the framework given in figure (1.0) above to examine how microfinance fosters unintended consequences 
and creates poor family cohesion through occurrences such as spousal disputes, polygyny practices and the neglect of perceived female domestic responsibilities.

Family and social cohesion is a construct of an active participatory process connecting a group of people through a notion of trust, shared commitment and reciprocity (Peterson and Hughey, 2004). It is an embodiment of healthy relationships that buffer against ill-being (see Falb et al., 2014; Fuligni and Tsai, 2015). Family and community support help to build social capital, resilience cohesion that impact positively on female empowerment (Baiyegunhi, 2014; Bernier and Meinzen-Dick, 2014; Milanov et al., 2015). However, existing research has not given adequate attention to the complexities of power relations within the family and the impact of role reversals arising from women improved financial position (Mayoux, 2001). While recent studies have raised concerns that microfinance for women can deepen conflict and further isolate women (Silverberg, 2014; Stam and Meier zu Selhausen, 2014) and also have negative impact on the welfare and education of girl children due to increased demand for child labour (Augsburg et al., 2012; Beaman et al., 2012), the empirical data on this subject is scant, particularly in African contexts. Thus, the paper examines the hypothesis:

$\mathrm{H}_{2}$ : Microfinance initiatives contribute to the demand for child-labour and impact negatively on school attendance for girls.

However, some studies have also suggested that women with better education are able to achieve better outcomes from micro-finance interventions, and overcome or mitigate potential negative consequences (Augsburg et al., 2012; Leatherman et al., 2011). Moreover, Raven and Le (2015) have argued that training female microcredit recipients in business skills will improve business performance and probably have other important effects. Thus, this paper seeks to test if education levels of women can reduce unintended poor family cohesion arising from access to micro-finance. This is captured in the following hypothesis:

$\mathrm{H}_{3}$ : The level of recipient education positively moderates the relationship between poor family cohesion and MFI`s services for women`s empowerment. 


\section{CULTURAL AND INSTITUTIONAL ISSUES}

Although Ghana is largely a matrilineal society, much of the power is still appropriated by men, both at home and in society. For example, in ancient Asante Kingdom, the only political office open to women is the queen mother. Aside from this, women past the age of menopause are allowed to occupy some spiritual leadership roles (Akyeampong and Obeng, 1995). Some have argued that Ghanaian women actually fared better in pre-colonial times, and that the marginalization of women in the distribution of power was worsened by the advent of colonialism as colonial administrators disregarded existing political arrangements and assigned more political power to native males (Bawa and Sanyare, 2013). This trend has continued to postcolonial times, where women are left on the periphery of political and economic power. The most visible- and arguably the most significant- manifestation of women's disadvantaged position in Ghana is economic disempowerment. Women, particularly those in rural areas, often spend most of their times attending to domestic duties at home, and have little or no opportunities for profitable commercial activities. Their vulnerability to poverty is associated with, and usually worsened by, unequal gender relations (Awumbila, 2006). It is in recognition of this problem that the United Nations declared, in the sustainable development goals (SDGs) that “...the achievement of full human potential and of sustainable development is not possible if one half of humanity continues to be denied its full human rights and opportunities", and that it "will work for a significant increase in investments to close the gender gap and strengthen support for institutions in relation to gender equality and the empowerment of women at the global, regional and national levels" (United Nations, 2015).

The underdeveloped financial environment, the persistent finance gap, financial exclusion, and income distribution inequalities in Ghana impede female economic engagement and negatively impacts economic development (Banerjee et al., 2013; Klugman et al., 2014) found that commercial banks in Ghana lack the strategies to target women entrepreneurs. Conversely, Maldonado and González-Vega (2008) reported that some microfinance programs generate negative effects of child-labour that weakens family relationships and negatively impacts women's wellbeing. It is therefore important to examine microfinance effects on women in Ghana within a framework of the current cultural and behavioural 
dimensions with the view to encouraging entrepreneurial uptake for women, while minimising potential negative impacts.

\section{Women`s empowerment}

Evaluations of household economics suggest gender inequalities are the result of deficient power structures in African families. Due to their low financial status, women have weaker bargaining power. Microfinance have a poverty reducing effect and improves female psychological and social empowerment in Ghana, reinforcing their confidence and selfesteem to actively participate in household and community decision making processes (Annim and Alnaa, 2013; Halkias et al., 2011). Conversely, lack of asset ownership and access to credit impedes entrepreneurial growth in Africa (United Nations, 2009), and these constraints are often greater for female entrepreneurs (Goltz et al., 2015). In Sub-Saharan Africa, women have limited access to finance despite producing more than $80 \%$ of the food in the region (Jalbert, 2000).

Aggarwal et al. (2015) report that women borrowers have a greater social impact; yet the gender gap in access to finance remains unfavourable to women in Ghana. Women have the potential to enter entrepreneurship and make a greater contribution to the GDP of Ghana`s economy. However, the heavy dependence of women on male family members suppresses their entrepreneurial attributes, and adversely impact their family and economic well-being. Moreover, inefficiency and the cost of microfinance impede women's ability to escape poverty (Schindler, 2010).

In theory, scholars have argued that microfinance gender targeted strategy has an economic justification in that women clients have lower write-offs, lower credit loss provisions, less risky loan portfolios, and good repayment character. For example, Ghanaian women were found to be well organised, with low default rates and higher returns on lending portfolios (Lindvert, 2006). Ghanaian women as debtors are considered to be more passive, submissive and vulnerable. These traits make them more reliable borrowers.

In spite of the argument in favour of women microfinance, targeted microfinance gender policy is often not the preferred strategy of many microfinance institutions. Some studies 
have shown that MFIs in Africa sometimes identify family heads as a channel through which they can deliver loans to individuals in the family for enterprise development (Gobezie, 2009). In effect, the heads of families in Africa, who are often men, control the resources they receive on behalf of women (Tamale, 2004). This denial of access to finance disempowers women from gaining self-sufficiency through enterprise. The traditional family model in Ghana, in which men dominate the family structure, enables them to use finance as a means of exercising control over the household. The absence of robust legal systems in Ghana gives rise to additional complex cultural, social issues and creates an environment that generates a set of outcomes that disempower women.

The intrinsic nature of domestic responsibilities and managing a business constrains the work-life balance for female entrepreneurs in Ghana. Enterprises require a high level of commitment that often strains family relationships and cohesion. Enterprise, if successful, provides financial empowerment to women that in turn alter the social and economic dynamics of family. In African countries, men who are successful in their use of microfinance to exit poverty are also more likely to marry several women to reflect their status and prosperity (Gibson and Mace, 2007). In this context, microfinance may have the undesirable consequences of instigating humiliation and domestic abuse by male spouses. Whilst microfinance has generated considerable interest in the economic development literature with respect to its impact on poverty alleviation, its contribution towards family and social cohesion in Ghana raises some fundamental questions which remain unanswered.

This study focused on clients of Opportunity International Savings and Loans Limited (OI); the single largest provider of microfinance to women in Ghana. OI provides loans using individual and group lending. Group lending was examined due to the unique nature of the approach. Using a peer screening mechanism, the women select members into groups to receive loans without providing any collateral. The group members undertake to enforce loan contracts. Therefore, anytime a group member defaults in repayments the group is obliged to pay the loan to avoid losing access to future credit from OI. The loan size for the women entrepreneurs investigated is between GHs. 250 and GHs. 5,000. 
METHOD

This study adopts the approach of Carullo et al. (2015) to match perception with facts, by tabulating information derived from the questionnaires to determine both the intended and unintended consequences of implementing microfinance projects. Carullo et al. (2015) suggested that often, data acquired through questionnaires and manipulated on the background of a notion of triadic closure has the potential to unearth relationships that reflect three dimensions of cohesion and how it may impact microfinance beneficiaries; namely the presence of conflict in a family is an indicator of lack of trust. Secondly, trust and social cohesion, are a construct of an active participatory process connecting a group of people through a notion of trust (Peterson and Hughey, 2004). Lastly, trust underpins the concepts of conflict and social cohesion in families and societies (Misztal, 1996). These three narratives were used to understand how negative trust, conflict and poor social cohesion in family relationships emerge as by-products of microfinance programs in Ghana.

Therefore, a mixed method approach was used to investigate the impact of microfinance on family cohesion in beneficiary communities in Ghana. The study adopts a cross sectional quantitative data survey analysis on a sample of 1200 selected microenterprises owned by women operating in Ghana. The main study questionnaire was developed based on preliminary focus group discussions and pilot questionnaires. Having carried out the pre-tests and final revision, the final questionnaire comprised of three sections: (1) personal and family information, (2) quantifiable information using the Likert scale and semi-structured questions. In section 3, the sample consisted of women who took loans 2, 3 and 4 years earlier and served as the respondents for this study because of their experience as beneficiaries of a loan. In total, 264 valid responses were obtained from a sample of 1200 microenterprises approached, a response rate of 22 per cent that compares favourably when benchmarked with similar studies (see for example; Alabi et al., 2007).

However, the study found no significant difference between early and late respondents, which demonstrates evidence of the lack of non-response bias. To gain a deeper appreciation of emerging issues from the statistical evidence, 30 semi-structured interviews were carried out with women entrepreneurs to corroborate the findings reported from the questionnaire, 
following the example of Skovdal (2010).

\section{Variables}

In order to test the hypotheses, a set of variables relating to the nature of the links between family cohesion, dependent variable and independent variables are summarised in Table 1. Evidence from Table 1 shows the Cronbach alpha values and their respective factor loadings.

\section{[Table 1 about here]}

The main dependent variable is family cohesion $(\mathrm{COH}) . \mathrm{COH}$ is measured in terms of spousal disputes, polygyny practice and perceived neglect of female domestic responsibilities. The Cronbach alpha score of 0.77 was obtained as the reliability score, which is also within (Hair et al., 2006) threshold reliability level. This study also adopt MFS provision as the main independent variable. Four items on a five point Likert scale measure MFS. Each respondent was asked their individual response on the benefits of the use of each of these services with a 5 point Likert scale of (1) strongly disagree and (5) strongly agree. The Cronbach alpha of 0.78 indicates a high reliability score (Adomako et al., 2016). Also, separate individual dummies were created for each of the four (4) MFS provided as separate independent variables. Following previous studies by Karlan and Valdivia (2011) and (Usman, 2015), the study controlled for education, location, age and firm size; as these factors have been reported to have intra relationship (Karlan and Valdivia, 2011; Usman, 2015) and their inclusion accounts for any exigencies that may affect the model. Detailed definitions of all the variables included in the model are presented in Table 2 below.

\section{[Table 2 about here]}

\section{Empirical Approach}

Following existing experiments of entrepreneurial analysis (Adomako et al., 2016; Adomako and Danso, 2014), the study moderated hierarchical regression analysis to estimate the relationship between microfinance success for women's enterprise (empowerment) and poor family cohesion in beneficiary communities. This study adopted the approaches of these previous entrepreneurial studies and similar other ones (Cadogan et al., 2006) to develop an 
interactive model used to estimate the moderating impact of education on the success of MFI services for women's empowerment and family cohesion. To test the robustness of the model the data was tested for multicollinearity, heteroscedasticity, and serial correlation. The correlation matrix for all the continuous variables suggested that none of the variables had coefficients greater than the threshold of 0.87 or 0.97 , consistent with the results reported by Field (2005). Using the robust standard error, the models (1) and (2) were checked for the presence of heteroscedasticity and serial. The models.

$$
\begin{aligned}
& \mathrm{COH}=\beta_{-} 0+\beta_{-} 1 X+\beta_{-} 2 Z+\varepsilon \\
& \mathrm{COH}=\beta_{-} 0+\beta_{-} 1 X+\beta_{-} 2 Z+\beta_{-} 3 X N+\varepsilon \\
& \mathrm{COH}=\beta_{-} 0+\beta_{-} 1 X+\beta_{-} 2 Z+\beta_{-} 3 C T+\varepsilon
\end{aligned}
$$

Where:

$\mathrm{COH}$ is the main dependent variable. $\mathrm{X}$ denotes the independent variable MFS. Where MFS is for specification (1) and (2). Whilst training, social capital, savings and credit for specification (3). Z represents control variables (Firm Size, Education, Location and Age) that may influence family cohesion $(\mathrm{COH}) . \mathrm{XN}$ represents the interaction between access to MFS and education (EDU). CT denotes the interactive term for credit and training. $\boldsymbol{\varepsilon}$ represents the idiosyncratic shocks. $\beta_{-}(1)$ and $[\beta \rrbracket-(2)$ are vectors of the parameters to be estimated. These variables are defined in Table 2 .

\section{Questionnaire Results}

Table 2 presents the descriptive statistics of all the variables adopted for the study. The average mean score for poor family cohesion is 4, suggesting that the success of microfinance for women's enterprise development could result in poor family cohesion. The study also find an average score of 4 , for access to MFI services, suggesting that majority of the respondents have been able to access at least one of the four services offered by the MFIs. 
The average age of entrepreneurs and firm size were found to be 38 years and 8 employees respectively. The results also reveal that about 70 per cent are educated at tertiary level. Furthermore, 70 per cent of the micro businesses are located in the capital city of Ghana, Accra.

\section{[Table 3 about here]}

The correlation matrix results reported in Table 4 indicate a significant and positive $(0.588, \mathrm{p}<0.01)$ association between poor family cohesion $(\mathrm{COH})$ and successful use of microfinance services (MFS) by women. Poor family cohesion and FIRMSIZE are significant and positively correlated $(0.630, \mathrm{p}<0.01)$ and $(0.195, \mathrm{p}<0.05)$ respectively. The control variables also demonstrated a positive and significant correlation $(0.113, p<0.1)$ between age (Age) and Firm size (FIRMSIZE). However, none of the variables had their coefficients greater than the threshold of 0.87 or 0.97 as suggested by Field (2005). Therefore, their inclusion in the multiple regression analysis does not create the problem of multicollinearity.

\section{[Table 4 about here]}

The regression results in Table 5 present the results of estimation of the relationship between poor family cohesion $(\mathrm{COH})$ and the successful use of microfinance services (MFS) by women. The table also shows evidence of the moderating impact of education upon the relationships between microfinance services and poor family cohesion. The results of Model 1 show a positive and significant $(35.54, \mathrm{p}<0.01)$ relationship between MFS on $\mathrm{COH}$ indicating that the outcomes of female access and use of MFI services could result in poor family cohesion $(\mathrm{COH})$. This result confirms the first hypothesis $\left(\boldsymbol{H}_{\boldsymbol{l}}\right)$ and is consistent with existing literature on the development and growth of women entrepreneurs (Chimthanawala, et al., 2015).

\section{[Table 5 about here]}

In terms of the control variables, the study finds a significantly $(-0.694, p<0.01)$ negative relationship between the level of education of women and poor family cohesion. The results suggest that more educated females are able to minimise the factors of poor family cohesion thus confirming the second hypothesis $\left(\boldsymbol{H}_{2}\right)$ and in line with findings reported by 
(Samarakoon and Parinduri, 2015) that level of education impacts positively on female entrepreneurial traits in middle-income countries. This investigation also found FIRMSIZE to be significant and negatively $(-0.701, \mathrm{p}<0.01)$ related to $\mathrm{COH}$. This is consistent with findings of Bonomo et al. (2015 and Nyakuma et al. (2016) Damijan et al (2015) that since large business have a large pool of resource base, they utilise these resources to reduce poor family cohesion instigators. However, the study did not find any significant relationship between age (AGE), location (LOC) and $\mathrm{COH}$.

However, in the second section of Table 5 (Model 2), the study estimate the moderating impact of education on the relationship between poor family cohesion $(\mathrm{COH})$ and microfinance services (MFS). It is argued that entrepreneurship education enables women to maximise the services of MFI's and relationships between highly educated women and positive family cohesion is more pronounced. Consistent with the second hypothesis $\left(\boldsymbol{H}_{2}\right)$, education was found to be significant and positively $(0.812, \mathrm{p}<0.01)$ moderate the relations between poor family cohesion $(\mathrm{COH})$ and microfinance services (MFS) for women's empowerment. This study also find the direct relationship between poor family cohesion $(\mathrm{COH})$ and microfinance services $(\mathrm{MFS})$ to be significantly positive $(23.41, \mathrm{p}<0.01)$ which is consistent with evidence of Model 1. In terms of the control variables, education and firm size remain negatively significant $(-2.895, \mathrm{p}<0.01 ;-0.793, \mathrm{p}<0.01)$ respectively. Also, location was found to be significantly positive $(1.815, \mathrm{p}<0.05)$ in Model 2 . However, the study did not find any significant relationship between AGE and $\mathrm{COH}$.

In order to further enhance the robustness of the results, the four individual components of the microfinance institution services were disaggregated

\section{[Table 6 about here]}

Interview Results

\section{Descriptive Statistics}

Table 7 presents results of summary statistics of face-to-face interviews with thirty married women respondents. The average age of the male category interviewed was 46 years, a lower of 34 and upper age of 58 years. Respondents were married for an average of 18 years and 
had 6 children. However, in the second category, the average female respondent was about 38 years, married for an average of 16 years and with an average of 5 children.

\section{[Table 7 about here]}

Economic activity and income generation through self-employment enable women to contribute towards household income and decision-making processes. Respondents acknowledged that the microfinance loan enabled them to engage in micro-enterprise that raised their income, status and respectability. Women entrepreneurs intentionally use enterprise activity supported by micro finance to consolidate their position in society through gaining purchasing power and independence. The women reported that asset deepening and enterprise size confer power. One of the respondents said that:

"Since acquiring additional sewing machines, protective clothes and employing additional workers, now I am taken seriously by family, friends and microfinance institutions" Respondent A

Respondent A, when quizzed, reported to have gained confidence when negotiating with men within family and externally. This has helped her in attracting a good quality of employees that improved the quality of garments, a reduction in absenteeism and improved productivity.

The interviews corroborate the findings that formal education improved women`s access to microfinance and productive use of the loan. Generally, those micro-entrepreneurs reported that their primary and secondary level education was a barrier to their success in starting and developing a microenterprise. Also, women with university level education said that their husbands felt threatened and disempowered, giving rise to domestic disputes. Some of the female respondents demonstrated limited skills and understanding of dispute resolution. This was more pronounced for microfinance recipients without formal education and living in poor areas. However, women who had received formal education were reported to be more successful in accessing microfinance and positioned to identify opportunities and to resolve conflicts that had the potential to engender negative family cohesion. This is reflected in the comments of two respondents below:

\footnotetext{
“...my ability to address some of these family problems is influenced by my level of education. I ensure my daughter is educated and not stay in the market to help sell provisions." Respondent D
}

14 
“.... my ability to address some family problems is influenced by my education and I am actively supporting my girls to get education.” Respondent F

Women in the sample recognised the role of trade associations in providing an enabling environment and to support microenterprises in accessing resources for their growth. Trade associations provide microenterprises the opportunity to participate in trade fairs to market their produce and establish business contacts that assist growth. One of the interviewees reported:

"I have participated in three trade fairs organised by my trade association. I have also been invited to trade fairs organised by other trade associations as a guest.” Respondent B

Respondents reported that access to microfinance fostered economic and social benefits for women. Participation in employment and support from MFIs inspires women to be empowered. However, further exploration through interviews revealed profound weaknesses in microfinance programs that impact negatively on female general wellbeing. All thirty women respondents in the survey reported that their school age girls assisted them with their businesses. Furthermore, they delegated household responsibilities to the girls thus, affecting their education. These findings confirm the third hypothesis $\left(\boldsymbol{H}_{3}\right)$. In cases where the women did not use the services of their daughters, they brought in young girls from other poor families to support the business and family responsibilities. Furthermore, fourteen of the respondents reported that the use of housemaids led to domestic disputes. Nine respondents reported that these disputes were normally associated with husbands suspected of having relationships with house maids. Seven women in the sample reported their husbands getting married to maids that led to spousal disputes and family breakdown. As one respondent observed,

\footnotetext{
"My husband is always fighting me because of my continuous stay in the shop. I leave the house for the shop by 6:00 am and come back home after 7:00 pm. To make matters worse my husband has married my housemaid as a second wife because he thinks I am no longer able to satisfy his physical or domestic needs.” Respondent E
} 
The analysis suggests that domestic violence and polygyny are two of the consequences of women entering enterprises. Five of the respondents reported they prefer to stay overnight at the market running their business than to go home to abusive husbands or rivals.

The analysis of the women's responses suggests that the success of micro enterprises displaces established cultural practices and norms. Success in women's enterprise had implications for girl child labour. This is similar to the findings of Klugman et al. (2014) and those described by (Basnet, 2015; Beaman et al., 2012) about a general decline in girl-child education due to women owned enterprises.

\section{DISCUSSION}

This study found that microfinance promotes female entrepreneurship in Ghana. Female empowerment is generally suggested as a key driver for MFIs reaching out to women clients. However, the findings of this study in comparison with the existing literature (Mazumder and Wencong, 2015; Siwale and Ritchie, 2012) suggest there is an insurgence of polygyny practice due to availability of microfinance. Also, women's success with microfinance destabilises the family power structure and creates conflict due to perceived neglect of domestic responsibilities. This is attributed to women spending more time on their business instead of their domestic responsibilities. The male spouses feel threatened by female independent decision making, and this gives rise to family conflicts. Besides, the traditional role of men is challenged, and to regain that authority they find alternative solutions through a second marriage or divorce. These outcomes are similar to Silverberg, (2014 and Stam and Meier zu Selhausen (2014) who found that whilst microfinance empowers women to be more independent, it can encourage intimate partner violence and theft in patriarchal societies. Moreover, these results are consistent with the arguments set out by Islam and Pakrashi (2014) and Olowu (2011) that MFIs that focus on microfinance loans, mentoring and training to empower women tends to overlook broader family dynamics and associated negative outcomes. The microfinance group-lending approach and the accompanying pressure have led to power struggles within families and amongst clans (Ali, 2014; Ashta et al., 2015; Mahoney, 2014). The findings of this study suggest that in most cases, employing children in microenterprise activities increased child-labour and reduced school enrolment. However, the 
adverse effects are more pronounced for girls than boys.

Consistent with evidence from the microfinance literature, the results of this study demonstrate that level of education, firm size and family cohesion are interlinked. Also, there is a strong relationship between level of education and benefits of the loan for recipients in Ghana. Karlan and Valdivia (2011) reported that education improves the managerial preparedness of micro entrepreneurs and impacts positively on family cohesion. Meanwhile, the study shows female microfinance clients in Ghana with a lower level of education are susceptible to severe incidences of poor family cohesion. Those with a higher level of education are relatively resilient. Evidence from Bonomo et al. (2015 and Damijan et al. (2015) has shown that larger microenterprises are able to leverage their greater resource advantage to reduce cases relating to poor family cohesion.

\section{CONCLUSION}

This study has examined the impact of microfinance on the success of enterprises, women empowerment and family well-being in Ghana. This research represents a significant step in designing more effective empowerment interventions through microfinance for women without disrupting family cohesion. The study challenges established conclusions about microfinance and concludes that there are some negative outcomes such as spousal disputes, polygyny practice and the neglect of perceived female responsibilities within the household, and these need to be considered in evaluations. Theoretically, microfinance helps women to exit poverty and gain better economic opportunities. However, the study suggests that women economic empowerment often precipitates or aggravates incidences of polygyny, family conflicts and adverse impacts on young girls' education and wellbeing. These effectually neutralise the benefits of microfinance. Thus, a major implication of this study is that, the family as a whole should be mentored to take on collective ownership and joint decisionmaking in the business before the credit facility is approved. This research challenges scholars, NGOs, lending managers, policy makers and stakeholders in the development sector to carry out more comprehensive evaluations of the impact that microfinance has on the wellbeing of women in order to achieve desired outcomes.

The main limitation of this study is that the above findings are restricted to Ghanaian female 
microfinance recipients. As a result, future research should broaden the scope of this microfinance inquiry. Perhaps, to include a bigger sample with a cross-country or cultural context that capture the unintended consequences of microfinance interventions targeted at women. Also, the deployment of a longitudinal study may refine the individual dynamics of the examined relationship due to the cross-sectional nature of this study.

\section{DECLARATION OF CONFLICT OF INTEREST}

The authors declared no potential conflicts of interests with respect to the authorship and/or publication of this article.

\section{FUNDING}

This research received no specific grant from any funding agency in the public, commercial, or not-for-profit sectors.

\section{REFERENCES}

Adomako, S. and Danso, A. (2014), "Regulatory environment, environmental dynamism, political ties, and performance", Journal of Small Business and Enterprise Development, Vol. 21 No. 2, pp. 212-230.

Adomako, S., Danso, A. and Ofori Damoah, J. (2016), “The moderating influence of financial literacy on the relationship between access to finance and firm growth in Ghana", Venture Capital, Vol. 18 No. 1, pp. 43-61.

Aggarwal, R., Goodell, J.W. and Selleck, L.J. (2015), "Lending to women in microfinance: Role of social trust", International Business Review, Elsevier Ltd, Vol. 24 No. 1, pp. 5565 .

Agyei, Y.A., Kumi, E. and Yeboah, T. (2016), "Is better to be a kayayei than to be unemployed: reflecting on the role of head portering in ghana??? informal economy", GeoJournal, Vol. 81 No. 2, pp. 293-318.

Aísa, M.G. (2014), Conditional Cash Transfers and Intimate Partner Violence among Mexican Couples: The Impact of Oportunidades on Psychological Abuse Prevalence.

Akyeampong, E. and Obeng, P. (1995), "Spirituality, Gender, and Power in Asante History", The International Journal of African Historical Studies, Vol. 28 No. 3, pp. 481-508.

Alabi, J., Alabi, G. and Ahiawodzi, A. (2007), "Effects of "“susu"” - a traditional microfinance mechanism on organized and unorganized micro and small enterprises ( MSEs ) in Ghana", African Journal of Business Management, Vol. 1 No. 8, pp. 201-208.

18 
Al-Dajani, H. and Marlow, S. (2013), "Empowerment and entrepreneurship: A theoretical framework", International Journal of Entrepreneurial Behaviour and Research, Vol. 19 No. 5, pp. 503-524.

Ali, H.M.A. (2014), "Blaming the poor and legitimizing coercive loan recovery strategies: Unveiling the dark side of NGO practices in bangladesh", Anthropologica, Vol. 56 No. 1, pp. 177-191.

Annim, S.K. and Alnaa, S.E. (2013), “Access to microfinance by rural women: Implications for poverty reduction in rural households in Ghana", Research in Applied Economics, Vol. 5 No. 2, pp. 19-41.

Ashta, A., Khan, S. and Otto, P. (2015), "Does microfinance cause or reduce suicides? Policy recommendations for reducing borrower stress", Strategic Change, Vol. 24 No. 2, pp. $165-190$.

Augsburg, B., Haas, R. De, Harmgart, H. and Meghir, C. (2012), Microfinance, Poverty and Education.

Awumbila, M. (2006), “Gender equality and poverty in Ghana: Implications for poverty reduction strategies", GeoJournal, Vol. 67 No. 2, pp. 149-161.

Baiyegunhi, L.J.S. (2014), "Social capital effects on rural household poverty in Msinga, KwaZulu-Natal, South Africa”, Agrekon, Vol. 53 No. 2, pp. 47-64.

Banerjee, A., Duflo, E., Glennester, R.G. and Kinnan, C. (2013), "The miracle of microfinance? Evidence from a randomized evaluation", MIT Department of Economics Working Paper No. 13-09, Vol. 7 No. 1, pp. 1-6.

Basnet, N. (2015), "Reviewing the child labour debates through Kamalahari system in Nepal”, South Asian Journal of Multidisciplinary Studies, Vol. 1 No. 5.

Bawa, S. and Sanyare, F. (2013), "Women's participation and representation in politics: perspectives from Ghana", International Journal of Public Administration, Vol. 36 No. 4, pp. 282-291.

Beaman, L., Duflo, E., Pande, R. and Topalova, P. (2012), "Female leadership raises aspirations and educational attainment for girls: A policy experiment in India", Science, Vol. 335 No. 6068 , pp. 582-586.

Bernier, Q. and Meinzen-Dick, R. (2014), "Resilience and social capital”, 2020 Conference, No. May, p. 26.

Blackden, C.M., Wodon, Q. and Shetty, S. (2006), “Gender, time use, and poverty in SubSaharan Africa: Foreword”, World Bank Working Paper, No. 73, available at:https://doi.org/10.1596/978-0-8213-6561-8.

Blattman, C., Green, E., Annan, J., Jamison, J., Aryemo, F., Carlson, N., Emeriau, M., et al. (2013), “Building Women' s Economic and Social Empowerment Through Enterprise: An Experimental Assessment of the Women's Income Generating Support ( WINGS )

19 
Program in Uganda", No. 1.

Bonomo, M., Brito, R.D. and Martins, B. (2015), “The after crisis government-driven credit expansion in Brazil: A firm level analysis", Journal of International Money and Finance, Vol. 55, pp. 111-134.

Cadogan, J.W., Cui, C.C., Morgan, R.E. and Story, V.M. (2006), "Factors facilitating and impeding the development of export market-oriented behavior: A study of Hong Kong manufacturing exporters", Industrial Marketing Management, Vol. 35 No. 5, pp. 634647.

Carullo, G., Castiglione, A., De Santis, A. and Palmeri, F. (2015), "A triadic closure and homophily-based recommendation system for online social networks", World Wide Web, Vol. 18 No. 6, pp. 1-23.

Chimthanawala, S.M.A., Naidu, K. and Shah, N. V. (2015), "Development and growth of women entrepreneurship of India", International Conference on Technology and Business Management, pp. 320-324.

Damijan, J.P., Kostevc, Č. and Polanec, S. (2015), “Access to finance, exporting and a nonmonotonic firm expansion", Empirica, Vol. 42 No. 1, pp. 131-155.

Darlington, P.S. and Mulvaney, B.M. (2014), Women, Power, and Ethnicity:working toward Reciprocal Empowerment, Routledge.

Falb, K.L., Annan, J., King, E., Hopkins, J., Kpebo, D. and Gupta, J. (2014), “Gender norms, poverty and armed conflict in Cote D'Ivoire: Engaging men in women's social and economic empowerment programming", Health Education Research, Vol. 29 No. 6, pp. 1015-1027.

Frey, C.B. and Osborne, M.A. (2015), “The future of employment: How susceptible are jobs to computerisation?", Technological Forecasting and Social Change, Vol. 114 No. 1, pp. 254-280.

Friggeri, A., Chelius, G. and Fleury, E. (2011), “Triangles to capture social cohesion”, Proceedings - 2011 IEEE International Conference on Privacy, Security, Risk and Trust and IEEE International Conference on Social Computing, PASSAT/SocialCom 2011, No. July, pp. 257-265.

Fuligni, A.J. and Tsai, K.M. (2015), "Developmental Flexibility in the Age of Globalization: Autonomy and Identity Development Among Immigrant Adolescents", Annual Review of Psychology, Vol. 66 No. 1, pp. 411-431.

Ganle, J.K., Afriyie, K. and Segbefia, A.Y. (2015), "Microcredit: Empowerment and disempowerment of rural women in Ghana", World Development, Vol. 66, pp. 335-345.

García-Rodríguez, F.J. (2012), "New methods in university entrepreneurship education: A multidisciplinary teams approach", Creative Education, Vol. 3 No. October, pp. 878883. 
Gibson, M.A. and Mace, R. (2007), "Polygyny, reproductive success and child health in rural Ethiopia: why marry a married man?”, Journal of Biosocial Science, Vol. 39 No. 2, p. 287.

Gobezie, G. (2009), "Sustainable rural finance: Prospects, challenges and implications", International NGO Journal, Vol. 4, pp. 12-26.

Goltz, S., Buche, M.W. and Pathak, S. (2015), "Political empowerment, rule of law, and women's entry into entrepreneurship", Journal of Small Business Management, Vol. 53 No. 3, pp. 605-626.

Hair, J.F., Black, W., Babin, B., Anderson, R. and Tatham, R. (2006), Multivariate Data Analysis, Pearson Prentice Hall., Vol. 6, available at:https://doi.org/10.1080/19447013008687143.

Halkias, D., Nwajiuba, C., Harkiolakis, N. and Caracatsanis, S.M. (2011), "Challenges facing women entrepreneurs in Nigeria”, Management Research Review, Vol. 34 No. 2, pp. 221-235.

Hughes, C., Bolis, M., Fries, R. and Finigan, S. (2015), "Women’s economic inequality and domestic violence: exploring the links and empowering women", Gender and Development, Taylor \& Francis, Vol. 23 No. 2, pp. 279-297.

Islam, A. and Pakrashi, D. (n.d.). "DEPARTMENT OF ECONOMICS The Microcredit Puzzle : Labour Supply Behaviour of Rural Households in microcredit in the intrahousehold and inter-sectoral distribution of labour supply . The data also en- microcredit on labour supply are not symmetrical across".

Jaggers, J.W., Church, W.T., Tomek, S., Hooper, L.M., Bolland, K.A. and Bolland, J.M. (2015), "Adolescent development as a determinant of family cohesion: A longitudinal analysis of adolescents in the mobile youth survey", Journal of Child and Family Studies, Springer US, Vol. 24 No. 6, pp. 1625-1637.

Jalbert, S.E. (2000), Women Entrepreneurs in the Global Economy.

Jin, B. (2015), "Family Cohesion and Child Functioning Among South Korean Immigrants in the Us : the Mediating Role of Korean Parent- Child Closeness and the Moderating Role of", No. May.

Karlan, D. and Valdivia, M. (2011), "Teaching entrepreneurship: Impact of business training on microfinance clients and institutions", Review of Economics and Statistics, Vol. 93 No. 2, pp. 510-527.

Klugman, J., Hanmer, L., Twigg, S., Hassan, T., McCleary-Sills, J. and Santamaria, J. (2014), Voice and Agency: Empowering Women and Girls for Shared Prosperity.

Kulkarni, V.S. (2011), Women's Empowerment and Microfinance: An Asian Perspective Study, available at:https://doi.org/ISBN 978-92-9072-280-9.

Lang, K. (2011), Poverty and Discrimination, Princeton University Press. 
Leatherman, S., Dunford, C., Metcalfe, M., Reinsch, M., Gash, M. and Gray, B. (2011), "Integrating Microfinance and Health Benefits, Challenges and Reflections for Moving Forward”, 2011 Global Microcredit Summit.

Lindvert, M. (2006), Sustainable Development Work and Microfinance- a Case Study of How ECLOF Ghana Is Working towards Financial Sustainability, Mid Sweden University.

Mahoney, K. (2014), "Microcredit: A model of empowerment for women? Dissenting Voices, Vol. 3 No. 1, pp6.

Maldonado, J.H. and González-Vega, C. (2008), "Impact of microfinance on schooling: Evidence from poor rural households in Bolivia", World Development, Vol. 36 No. 11, pp. 2440-2455.

Mayoux, L. (2001), “Tackling the down side: Social capital, women's empowerment and micro-finance in Cameroon", Development and Change, Vol. 32, pp. 435-464.

Mazumder, M.S.U. and Wencong, L. (2015), "Does microfinance impact on rural empowerment in Bangladesh? Differences between Governmental and NonGovernmental microfinance programs", Sustainable Development, Vol. 23 No. March, pp. 135-152.

Meth, P. (2013), "Millennium development goals and urban informal settlements: unintended consequences", International Development Planning Review, Vol. 35 No. 1, pp. v-xiii.

Milanov, H., Justo, R. and Bradley, S.W. (2015), "Making the most of group relationships: The role of gender and boundary effects in microcredit groups", Journal of Business Venturing, Elsevier Inc., Vol. 30 No. 6, pp. 822-838.

Misztal, B. (1996), Trust in Modern Societies: The Search for the Bases of Social Order, John Wiley.

Nyakuma, D.D., Jaleel, A., Shittu, K., Ojobo, H. and Ivase, T.J. (2016), “Challenges of adopting information and communications technology by small and medium enterprises in Nigeria", Journal of Multidisciplinary Engineering Science and Technology, Vol. 3 No. 1, pp. 3766-3776.

Ogato, S. (2013), “The quest for gender equality and womens empowerment in least developed countries: Policy and strategy implications for achieving millennium development goals in Ethiopia", International Journal of Sociology and Anthropology, Vol. 5 No. 9, pp. 358-372.

Olowu, D. (2011), "Mainstreaming women, equating men: Charting an inclusionary approach to transformative development in the African decade for women", Law, Democracy \& Development, Vol. 15, pp. 1-22.

Opsahl, T. (2013), “Triadic closure in two-mode networks: Redefining the global and local clustering coefficients", Social Networks, Vol. 35 No. 2, pp. 159-167.

Peterson, N.A. and Hughey, J. (2004), "Social cohesion and intrapersonal empowerment: 
Gender as moderator", Health Education Research, Vol. 19 No. 5, pp. 533-542.

Raven, P. and Le, Q. V. (2015). "Teaching business skills to women: Impact of business training on women's microenterprise owners in Vietnam", International Journal of Entrepreneurial Behavior and Research, Vol. 21 No. 4, 622-641.

Salia, P.J. (2014), "The effect of microcredit on the household welfare (Empirical Evidences from women micro-entrepreneurs in Tanzania)", International Journal of Academic Research in Business and Social Sciences, Vol. 4 No. 5, pp. 259-272.

Samarakoon, S. and Parinduri, R.A. (2015), "Does education empower women? Evidence from Indonesia", World Development, Vol. 66, pp. 428-442.

Schindler, K. (2010), "Credit for what? Informal credit as a coping strategy of market women in northern Ghana”, Journal of Development Studies, Vol. 46 No. 2, pp. 234-253.

Seidu, A. and Bambangi, S. (2006), "Micro-credit poverty alleviation: An analysis of the performance of women in micro-credit activities in the Kassena Nankana district of Ghana", Ghana Journal of Deevlopment Studies, Vol. 3 No. 2, pp. 41-56.

Silverberg, S. (2014), "One size does not fit all: A study of microfinance practices in Peru", Undercurrent, Vol. 10 No. 2, pp. 45-53.

Siwale, J.N. and Ritchie, J. (2012), "Disclosing the loan officer's role in microfinance development”, International Small Business Journal, Vol. 30 No. 4, pp. 432-450.

Skovdal, M. (2010), "Community relations and child-led microfinance: a case study of caregiving children in Kenya”, AIDS Care, Vol. 22 No. sup2, pp. 1652-1661.

Srivinisa, A.T. and Shivanna, B.K. (2014), "Micro-finance and women empowerment in Old Town Yalahanka, Banglore North Taluk", International Journal of Retailing \& Rural Business Perspectives, Vol. 3 No. 4, p. 1319.

Stam, E. and Meier zu Selhausen, F. (2014), Husbands and Wives. The Powers and Perils of Participation in a Microfinance Cooperative for Female Entrepreneurs.

Stromquist, N.P. (2015), “Women's wmpowerment and education: Linking knowledge to transformative action”, European Journal of Education, Vol. 50 No. 3, pp. 307-324.

Sveiby, K., Gripenberg, P., Segercrantz, B., Eriksson, A. and Aminoff, A. (2009), "Unintended and undesirable consequences of innovation", XX ISPIM Conference The Future of Innovation, No. June 2015, pp. 1-16.

Tamale, S. (2004), "Gender trauma in Africa: enhancing women's links to resources", Journal of African Law, Vol. 48 No. 1, pp. 50-61.

United Nations. (2009), Rethinking Poverty: Report on the World Social Situation 2010, The Effects of Brief Mindfulness Intervention on Acute Pain Experience: An Examination of Individual Difference, Vol. 1, available at:https://doi.org/10.1017/CBO9781107415324.004. 
United Nations. (2015), Transforming Our World: The 2030 Agenda for Sustainable Development, Vol. 50071, available at:

http://www.unfpa.org/sites/default/files/resource-pdf/Resolution_A_RES_70_1_EN.pdf.

Usman, A. (2015), “Analysing the impact of micro-finance on poverty reduction”, Journal of Poverty, Investment and Development -An Open Access International Journal, Vol. 13, pp. 104-116.

Zeidan, S. and Bahrami, S. (2011), "Women entrepreneurship in GCC: A framework to address challenges and promote participation in a regional context", International Journal of Business and Social Science, Vol. 2 No. 14, pp. 100-107. 


\section{Table 1: Summary of predictor measures}

This table shows the Cronbach alpha values and their respective factor loadings. Composition reliability is estimated as the sum of the square roots of the item-squared multiplied by correlation squared and dived by the same quantity plus the sum of the error variance. All variables are defined in Table 2.

$\begin{array}{llllrr}\text { Variable } & \text { Number of item } & \text { Scale format } & \text { Cronbach's alpha } & \text { AVE } & \text { CR } \\ \text { MFS } & 4 & 1 \text { to 5 Likert scale } & 0.78 & 0.72 & 0.69 \\ \text { COH } & 3 & 1 \text { to } 5 \text { Likert scale } & 0.77 & 0.80\end{array}$




\section{Table 2: Variables and measurement}

\section{Variable \\ $\mathrm{COH}=$ Poor Family Cohesion \\ Independent Variable \\ MFS $=$ Microfinance Services \\ AGE $=$ Age of female entrepreneurs \\ EDU $=$ Education Level of entrepreneurs \\ LOC $=$ Location}

Firmsize $=$ Firmsize

\section{Measurement}

Poor Family Cohesion is measured by three items (3): (a) spousal disputes, (b) polygyny practice and (c) perceived neglect of female domestic responsibilities. In the questionnaire, respondents were asked to tick whether they agree or disagree that access to and use of MFI services for women`s empowerment result in each of the three measured outcome variables for poor family cohesion. We anchored each of these responses on a five-point Likert scales of "1" strongly disagree and " 5 " strongly agree in accordance with the guidelines by Raaijmakers et al. (2009).

Microfinance Services is measured by the four main services provided by Microfinance institutions (training, social capital, savings and credit). This was measured on a five -point scale with anchors ranging from strongly disagree to strongly agree.

\section{Control Variable}

We measured firm age as the number of years the firm has been in operation Firm age was log transformed to normalise its distribution and then standardised before inclusion in the research model

We captured education as any female microenterprise owner who has received at least up to Junior High School training. We capture this as " 1 " Yes if female micro-entrepreneurs have at least a Junior High School training and "0" No otherwise.

Firms were selected only from suburbs of Accra (Dome, Ordokor and Circle). Location information was used to test whether it affects relationships between microfinance services and family cohesion. We capture this as "1" Yes if female micro-entrepreneurs have their businesses operating in each of these locations and " 0 " No otherwise.

We measured firm size as the natural logarithm of the number of employees of the firm. 


\section{Table 3: Descriptive Statistics}

The table provides the sample characteristics across the 260 microfinance. The table also presents the results of collinearity test after the residual centring approach. The results from the VIF indicate that there is no issue of multicollinearity among the variables. All variables are defined in Table 2.

\begin{tabular}{lccccc}
\hline & & & & \multicolumn{2}{c}{ Collinearity statistics } \\
\hline VARIABLE & OBS & MEAN & SD & VIF & TOLERANCE \\
\hline COH & 260 & 4.22 & 1.06 & 0.87 & 1,135 \\
MFS & 260 & 3.83 & 0.03 & 0.88 & 1.140 \\
LOCATION & 260 & 70.07 & 0.50 & 0.95 & 1,104 \\
EDU & 260 & 69.61 & 0.46 & 0.91 & 1,104 \\
AGE & 260 & 39 & 12.6 & 0.83 & 1,204 \\
FIRMSIZE & 260 & 7.8 & 4.38 & 0.92 & 1,080 \\
\hline
\end{tabular}


Table 4: Correlation Matrix

The table provides Pearson correlation coefficients for the 260 microfinance. All variables are defined in Table 2 . Correlation is significant at $* * * \mathrm{p}<0.01, * * \mathrm{p}<0.05, * \mathrm{p}<0.1$

\begin{tabular}{lllllll}
\hline & COH & MFS & AGE & EDU & LOCATION & FIRMSIZE \\
COH & 1.000 & & & & \\
MFS & $0.588^{* * *}$ & 1.000 & & & & \\
AGE & 0.024 & -0.020 & 1.000 & & & \\
EDU & $0.630^{* * *}$ & -0.053 & 0.074 & 1.000 & & 1.000 \\
LOCATION & -0.097 & -0.024 & -0.006 & -0.089 & 1.000 & 0.097 \\
FIRMSIZE & $0.195^{* *}$ & -0.035 & $0.113^{*}$ & 0.039 & & \\
\hline
\end{tabular}


Table 5: Regression Analysis for Microfinance Relationship with Poor Family Cohesion

This table reports the results of estimation of the relationship between poor family cohesion $(\mathrm{COH})$ and the successful use of microfinance services (MFS) by women across 260 Ghanaian microfinance institutions. All variables are defined in Table $2 . * * *, * *$ and $*$ represent coefficients significant at the $1 \%, 5 \%$ and $10 \%$ levels correspondingly (two-tailed tests). T-statistics are in parentheses

\begin{tabular}{|c|c|c|}
\hline & (1) & (2) \\
\hline VARIABLES & $\mathrm{COH}$ & $\mathrm{COH}$ \\
\hline \multirow[t]{2}{*}{ MFS } & $35.54 * * *$ & $23.41 * * *$ \\
\hline & $(7.90)$ & $(6.44)$ \\
\hline \multirow[t]{2}{*}{ AGE } & 0.0354 & 0.0238 \\
\hline & $(0.98)$ & $(0.74)$ \\
\hline \multirow[t]{2}{*}{ MFS * EDU } & & $0.812 * * *$ \\
\hline & & $(4.71)$ \\
\hline \multirow[t]{2}{*}{ EDU } & $-0.694 * * *$ & $-2.895 * * *$ \\
\hline & $(-9.35)$ & $(-5.94)$ \\
\hline \multirow[t]{2}{*}{ LOCATION } & 1.076 & $1.815^{* * *}$ \\
\hline & $(1.26)$ & $(2.61)$ \\
\hline \multirow[t]{2}{*}{ FIRMSIZ } & $-0.701 * * *$ & $-0.793 * * *$ \\
\hline & $(-7.19)$ & $(-9.43)$ \\
\hline \multirow[t]{2}{*}{ CONSTANT } & $-47.48 * * *$ & $-15.95^{*}$ \\
\hline & $(-4.70)$ & $(-1.85)$ \\
\hline OBSERVATIONS & 260 & 260 \\
\hline R-SQUARED & 0.689 & 0.791 \\
\hline
\end{tabular}




\section{Table 6: Individual effects of Microfinance services on Poor Family Cohesion}

This table reports the results of estimation of the relationship between poor family cohesion $(\mathrm{COH})$ and Individual Microfinance services (Credit, Savings, Social capital and Training) by women across 260 Ghanaian microfinance institutions. All variables are defined in Table 2 . ***, ** and * represent coefficients significant at the $1 \%, 5 \%$ and $10 \%$ levels correspondingly (two-tailed tests). $t$-statistics are in parenthese

\begin{tabular}{ll}
\hline & $(1)$ \\
& $\mathrm{COH}$ \\
& $(4.88)$ \\
CREDIT & $0.439^{* * *}$ \\
& $(4.84)$ \\
SAVINGS & \\
& \\
SOCIAL CAPITAL & \\
& \\
TRAINING X CREDIT & \\
& \\
EDU & $-0.183^{* * *}$ \\
& $(-3.10)$ \\
FIRMSIZ & -0.0841 \\
& $(-0.46)$ \\
LOCATION & 0.426 \\
& $(0.27)$ \\
AGE & -0.0452 \\
& $(-0.73)$ \\
CONSTANT & $19.10^{* * *}$ \\
& $(6.37)$ \\
OBSERVATIONS & 260 \\
R-SQUARED & 0.1542
\end{tabular}

$(2)$
$\mathrm{COH}$

$(5.96)$
$0.518^{* * *}$
$(6.24)$
(3) $\mathrm{COH}$ $0.803^{* * *}$ (9.22)

$0.763^{* * *}$

(9.22)

$0.827^{* *}$

(12.49)

$0.765^{* * *}$

(9.52)

0.0230

(0.55)

$-0.775^{* * *}$

$(-11.25)$

$-0.764^{* * *}$

$(-9.07)$

1.260*

(1.95)

0.0452

(1.27)

1.136

(0.97)

260

0.8045 
Table 6: Summary Statistics and Univariate Analysis of Face to Face Interview respondent

The table presents results of the face to face interview response on the relationship between poor family cohesion $(\mathrm{COH})$ and the successful use of microfinance services (MFS) by women across Ghanaian microfinance institutions.

\begin{tabular}{|l|l|l|l|l|l|l|l|l|l|l|l|}
\hline Male Category & \multicolumn{9}{|c|}{ Female Category } & & \\
\hline \\
VARIABLE
\end{tabular}




\section{Page 33 of 33}

International Journal of Entrepreneurial Behaviour \& Research 